ENTREPRENEURSHIP AND SUSTAINABILITY ISSUES

ISSN 2345-0282 (online) http://jssidoi.org/jesi/ 2019 Volume 7 Number 1 (September)

http://doi.org/10.9770/jesi.2019.7.1(17)

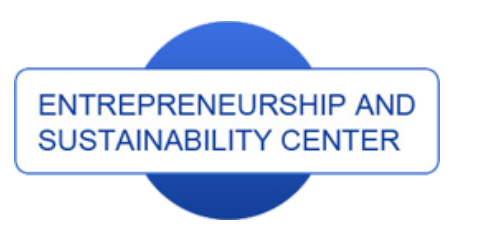

Publisher

http://jssidoi.org/esc/home

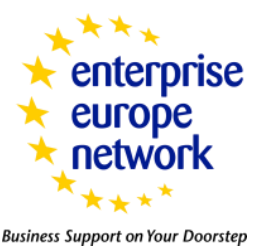

CASPA

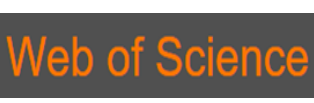

\title{
DEVELOPMENT OF ELECTRONIC BANKING: A CASE STUDY OF UKRAINE
}

\section{Valentyna Yakubiv ${ }^{1}$, Ruslana Sodoma ${ }^{2}$, Oksana Hrytsyna ${ }^{3}$, Natalia Pavlikha ${ }^{4}$, Tetiana Shmatkovska ${ }^{5}$, Iryna Tsymbaliuk ${ }^{6}$, Olga Marcus ${ }^{7}$, Iryna Brodska ${ }^{8}$}

\author{
${ }^{I}$ Vasyl Stefanyk Precarpatian National University, 76000, Shevchenko Street, 57, Ivano-Frankivsk, Ivano-Frankivsk region, \\ Ukraine \\ ${ }^{2,3}$ Lviv National Agrarian University, 80381 st. Volodymyra Velykogo, 1, Dublyany Zhovkivsky district, Lviv region, Ukraine \\ ${ }^{4}$ Lesya Ukrainka Eastern European National University, 43000, Voli Street, 13, Lutsk, Volyn region, Ukraine \\ 5, 6, 7 Lesya Ukrainka Eastern European National University, 43000, Vinnichenko Street, 28, Building $7(G)$, Lutsk, Volin \\ region, Ukraine \\ ${ }^{8}$ Lutsk National Technical University, 43000, Lvivska street, 75, Lutsk, Volin region, Ukraine
}

\author{
E-mails: ${ }^{1}$ yakubiv.valentyna@gmail.com , ${ }^{2}$ sodomaruslana@gmail.com , ${ }^{3}$ ogrytsyna@ukr.net, \\ ${ }^{4}$ prorectorscience@eenu.edu.ua, ${ }^{5}$ shmatkovska2016@gmail.com, ${ }^{6}$ tsymbaliukii ukr.net, ${ }^{7}$ oreola9@ukr.net, \\ 8brodska.irina80@gmail.com
}

Received 10 February 2019; accepted 5 July 2019; published 30 September 2019

\begin{abstract}
The article examines the practice of providing financial services in the conditions of security electronic business and outlines the preconditions for the transformation of financial services using various forms of electronic banking. The phases of development of Internet banking and use of mobile banking are considered. The international practice of electronic banking on the example of Poland with a detailed analysis of clients and the characteristics of the leading Polish banks is analyzed. The market of domestic Internet banking services is characterized and the main problems that hinder its development in modern conditions are revealed. The advantages and disadvantages of the wide dissemination of Internet technologies in Ukraine are formulated. Almost all banks that occupy leading positions in the market of banking services offer e-banking services, as it enables clients, without attending a branch of banks, to carry out a wide range of banking operations: to manage the volume of resources on their own account; exchange currency; make payments and transfers; pay for services of mobile communication, Internet, utilities, taxes, fines. The introduction of innovative forms of remote-servicing expands the profile of traditional risks and creates new sources of their occurrence. Therefore, the process of identifying security risks in the use of electronic banking, assessments and risk minimization techniques is a prospect for further research.
\end{abstract}

Keywords: bank; electronic banking; remote bank service; internet banking; mobile banking; innovations

Reference to this paper should be made as follows: Yakubiv, V.; Sodoma, R.; Hrytsyna, O.; Pavlikha, N.; Shmatkovska, T.; Tsymbaliuk, I.; Marcus, O.; Brodska, I. 2019. Development of electronic banking: a case study of Ukraine, Entrepreneurship and Sustainability Issues 7(1): 219-232. http://doi.org/10.9770/jesi.2019.7.1(17)

JEL Classification: G21, G23 


\section{ENTREPRENEURSHIP AND SUSTAINABILITY ISSUES}

ISSN 2345-0282 (online) http://jssidoi.org/jesi/

2019 Volume 7 Number 1 (September)

http://doi.org/10.9770/jesi.2019.7.1(17)

\section{Introduction}

Today, in conditions of hard competition, the quality of the bank is determined by the level of development of innovative technologies and ideas that greatly simplify the process of interaction between customers and the bank. Electronic banking is widespread in America and Europe in today's conditions is in demand in the Ukrainian market. In order to remain in the market, banks need to increase their competitiveness, for example, through the introduction of new services, the development of modern technology in order to meet the needs of customers. Remote service today serves as a modern tool in banking, which has not only mobility, but also high functionality, availability and security. The perspective of remote banking services requires a deeper theoretical study and practical aspects of its implementation, which indicates the relevance of this topic.

\section{Literature review}

The issue of electronic banking development is interesting for many domestic and foreign economists and practitioners such as S. Vakhnyuk (Vachnyk, 2003), O. Yesin (Jesina, 2013), O. Chub (Chyb, 2017), S. Voitschovska-Philippe (Wojciechowska-Filipek, 2010), C Zalesk, (Zaleska, 2007), M. Kisil (Kisiel, 2007), and others. In one article it is analyzed the current state of development of the banking network in Ukraine as one of the types of distance in the banking sector system and the essence of the concept of the Internet banking - its opportunities and advantages are determined (Jesina, 2013). But as the current state of Internet banking shows, there are still a number of unresolved issues that require new developments to determine the best ways to use ebanking. The author does not highlight the disadvantages of using remote banking services. The scientist S. Vakhnyuk notes that an alternative strategy that can ensure the competitive advantages of commercial banks should be based on the organization of remote customer service capabilities. For today, the servise of access of bank and client cooperation is possible within «client - bank» system. Some banks, working on the prospect, offer an on-line version of the "client-bank" that uses the Internet for information exchange (Vachnyk, 2003). However, we believe that this approach has its own disadvantages, because it requires the installation of specific software on the user's computer to provide the functions of the client interface, encryption, transmission and receipt of information. Therefore, we can say that the system «client - bank» does not fully address the issue of user independence from its geographical location.

Electronic banking includes such areas as online information service, digital money issue, electronic payments and settlements, as well as deposit and loan operations, currency and stock transactions carried out electronically. This definition is used Gracheva $\mathrm{M}$ as generalized and is adequate for all forms of electronic access of customers to banking services (Gracheva M, 2002). It is worth paying attention to the opinion of the scientist and agree with it.

Synthesis of bank financial management integrated technologies should involve consistency of indicators used as part of these technologies. For this purpose, they should reflect the strategic goals and be interrelated so that one can trace how changes in some indicators affect the others. This means that during the process of implementation of bank financial management integrated technologies priority should be given to the most significant indicators, such statements are highlighted by Iryna Chmutova in her work (Chmutova I., 2017). sufficiently pointed out by Bank Management, but there is insufficient implementation of banking technology.

At the same time, it should be noted that the available tools rely on different analytical methods to support integrated management technologies, leading to inconsistency of managerial decisions based on the analysis of different metrics. E. Bessonova, Boiar A. and T. Domkhokova deal with this problem by using balanced scorecard indicators for controlling purposes (Bessonova E., Boiar A.; 2016; Boiar et al. 2018). Another problem which has 


\section{ENTREPRENEURSHIP AND SUSTAINABILITY ISSUES}

ISSN 2345-0282 (online) http://jssidoi.org/jesi/

2019 Volume 7 Number 1 (September)

http://doi.org/10.9770/jesi.2019.7.1(17)

not been addressed by researchers is the need to consider the current stage of the bank's development when forming a set of analytical parameters underlying remote banking service.

Strengthening banking supervision with the use of Internet banking, highlighted in the work of Y. Romanenko and I. Chaplay. They describe the complexity of the internal construction of the functional system of transactions that are part of the banking supervision mechanism determines the need for a unified approach to harmonize the content and procedures for the implementation of these functions, which should ensure the effectiveness of supervisory activities in general (Romanenko Y.; Chaplay I., 2017).

Scientist T. Shevchuk proposes the basic factors for further development of Internet banking in Ukraine which will attract much more clients, increase speed and quality of service of client's cashless payments, develop functionality and services convenient and affordable for the clients, increase the safety of banking in general (Shevchuk T., 2015). Solutions of the specified questions are caused by relevance and timeliness of scope of a research.

The authors agree that the rapid development of computer and telecommunication technologies increases the efficiency of both the banking services themselves and their sales channels, greatly expanding the market and the geography of services that can be used by the client. However, issues related to the operation of various forms of electronic banking services, security and the use of innovative gadgets and technologies as e-banking tools are not sufficiently investigated.

The purpose of the study is the development of scientifically grounded proposals for improving efficiency of using the latest financial electronic technologies as new competitive services of a bank. The main issues that are investigated in the article are the international practice of electronic banking on the example of Poland and the analysis of domestic Internet banking services.

\section{Research methods}

The theoretical and methodological basis of the research is the basic provisions of modern economic theory, the work of leading domestic and foreign scientists on the issues of remote banking services. In article all materials are worked out by means of a complex of methods of scientific research, in particular the direct description of the studied phenomenon, processing of statistical information by means of economic methods of a research, representation of the received results by means of a tabular form and a graphic method.

The scientific novelty of the obtained results is represented by a set of theoretical and practical aspects of the research, namely proposals on the impact of technology development on the development of banking products and recommendations for the further development of various forms of electronic banking in Ukraine.

\section{Presentation of the main research material}

Electronic banking, as one of the ways to provide banking services, has gained widespread popularity in developed countries and gradually captures the Ukrainian financial and credit sector. It should be noted that customers are increasingly choosing easy access to services that they can use anywhere.

The Bank is one of the intermediary institutions, which makes possible the flow of funds from legal entities with a financial surplus for those who have a deficit. In this case, the bank accumulates and distributes the capital.

It is very important to value the tendencies of different asset classes which are in foreign reserves portfolio (Teresienè, D., 2018). 
ENTREPRENEURSHIP AND SUSTAINABILITY ISSUES

ISSN 2345-0282 (online) http://jssidoi.org/jesi/ 2019 Volume 7 Number 1 (September) http://doi.org/10.9770/jesi.2019.7.1(17)

The development of information technology plays an important role in the bank (Tsymbaliuk I., 2017). Electronic banking operations are characterized by the fact that the client is able to benefit from every service offered by the bank using an electronic device.

Electronic banking includes such areas as online information service, digital money issue, electronic payments and settlements, as well as deposit and loan operations, currency and stock transactions carried out electronically. This definition is used as generalized and is adequate for all forms of electronic access of customers to banking services (Gracheva et al, 2002).

In the process of stage development, forms of electronic banking changed according to the evolution of software tools and hardware means (Yakubiv V., 2015). The main forms of electronic banking are PC-banking, Internetbanking, mobile banking, video banking, tele-banking and self-service terminals (POS terminals and ATMs). Details are described in Figure 1.

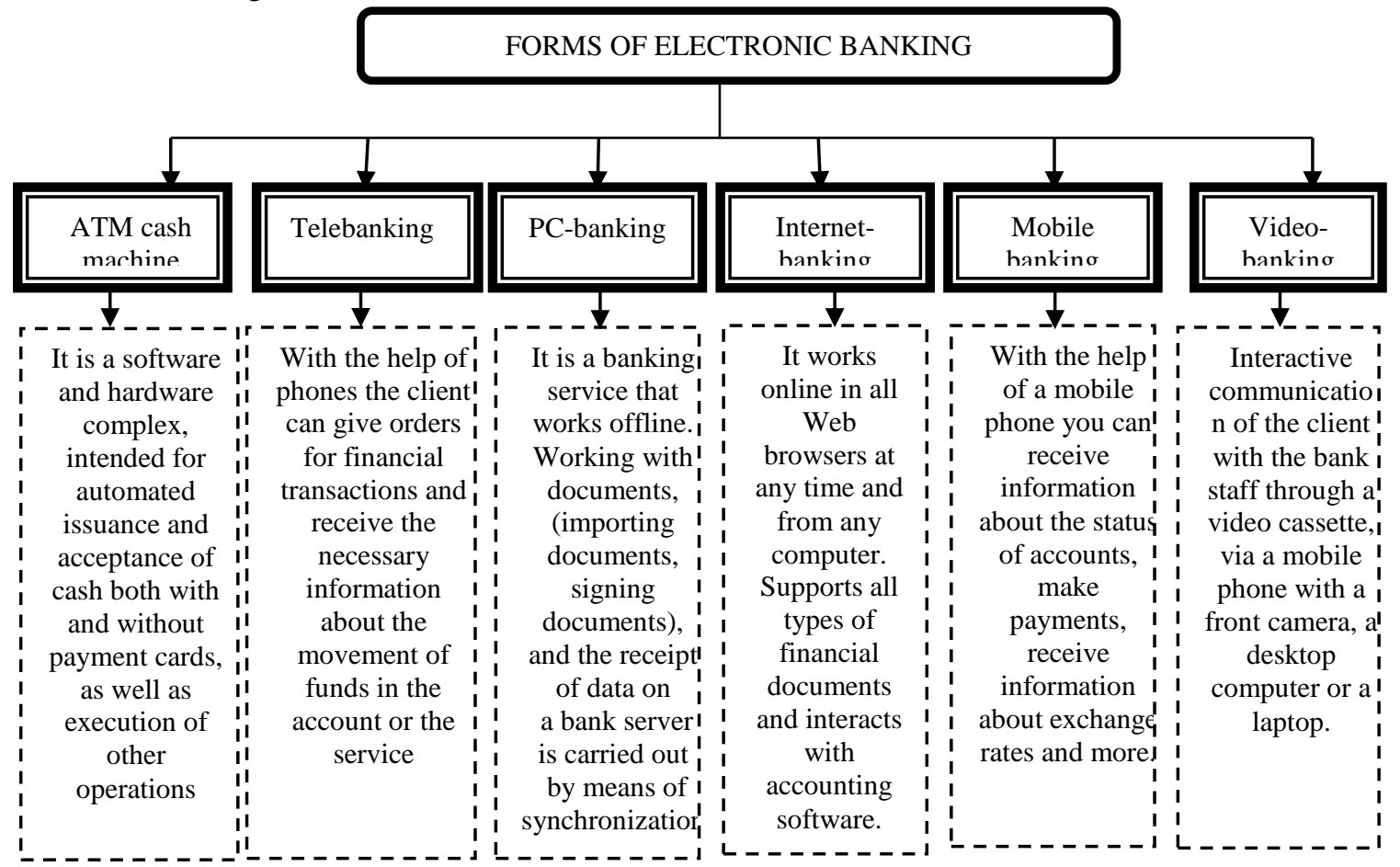

Fig. 1. Forms of Electronic Banking

Source: built by the authors

The vast majority of these forms are still functioning, but there is a clear tendency of prevalence of Internet banking and mobile banking. Mobile banking offers customer service, very similar to those offered by a traditional bank. The difference lies in the fact that due to the mobility of transactions, they are held for a short time, without the need to stand in queue at the branches of the bank and wait for the appropriate decision. Internet services are divided into two parts: the first one is information that is accessible to all users with Internet access without signing an agreement with the bank, and the second - operations that allow you to perform various actions on your account, but only after the agreement with the bank. After the transaction is signed, the client receives the login and password for the first time you sign in to your account. Other services are activated by the user through the website or the corresponding application of the given bank in the phone. The exception is products related to the assessment of creditworthiness, when the client must personally contact the bank.

The stage of development of Internet banking is shown in Figure 2. 


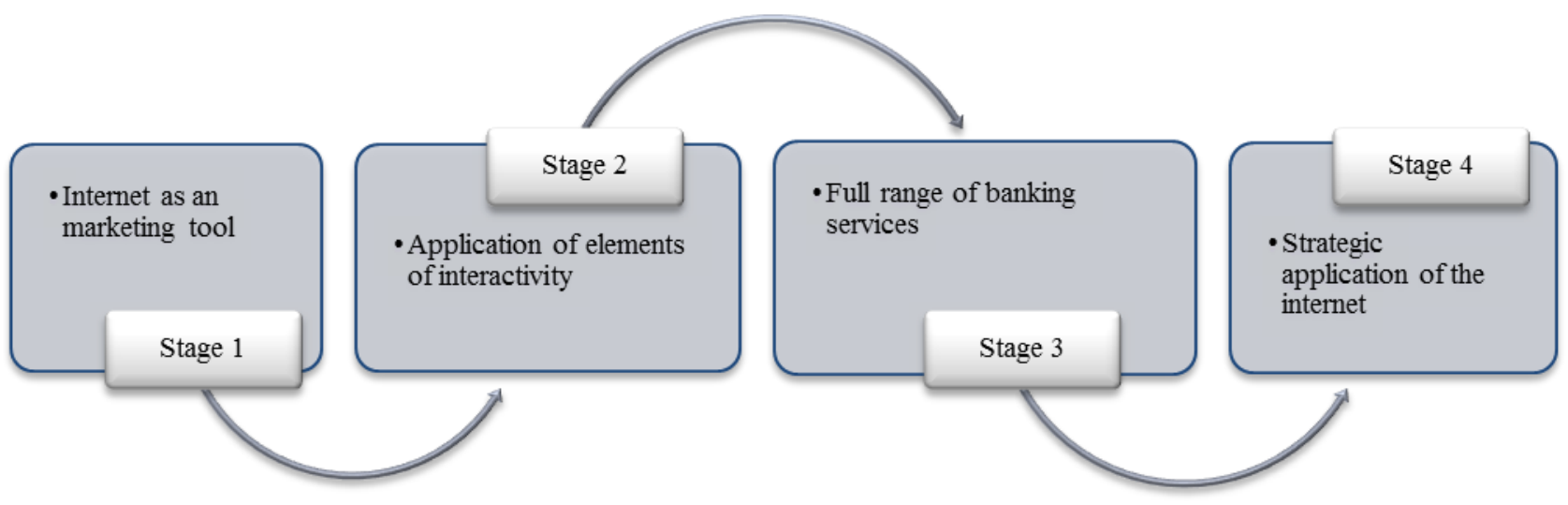

Fig. 2. Stages of Internet Banking Development

Source: own research based on (Wojciechowska - Filipek, 2010).

The first stage of Internet banking development includes marketing and promotion. At this stage, it is important to provide the client with the maximum amount of information related to the activities of the bank. The first step is to create a bank website, which should contain information related to the bank's activities, a list of services provided by the bank, an updated map of branches and ATMs, which allows the client to contact the bank by email. This will allow the dissemination of information among potential bank customers (Wojciechowska - Filipek, 2010). At the second stage of development - interactive elements are introduced on the existing web-site of the bank. The main goal is to motivate customers to visit the bank's website. The Bank offers such free tools as: calculators that allow you to calculate the loan, the schedule of repayment of the loan, also expects the bank' staff to facilitate the implementation of common tasks (Kisiel, 2007). The third stage allows banks to offer a full range of services and operations of the bank. For the first time, clients can manage their funds on accounts. All this thanks to the Internet. Establishing or terminating a deposit or checking transaction history is no longer a problem for the client. As a result, the bank becomes more reliable in the eyes of customers who prefer to use banking services over the Internet (Zaleska, M., 2007). The last stage of Internet banking development focuses on the fact that the bank uses the Internet for strategic purposes to collect and analyze customer information in order to sell its goods and services more effectively. Only at this stage, the bank offers an additional variety of investment services, and even insurance. While the bank's website is being turned into a portal, including financial information, stock quotes or other financial services that are available online (Kisiel, 2007). Banks, through modern technological solutions, offer new banking services and products adapted to take into account the individual needs of the customer. Banks offer customers the highest level of security through electronic signature, simple and strict authentication and encryption of data.

There are four business models of Internet banking («traditional bank», «virtual bank», «internet bank», «electronic financial supermarket»), the characteristics of which are shown in Figure 3. 


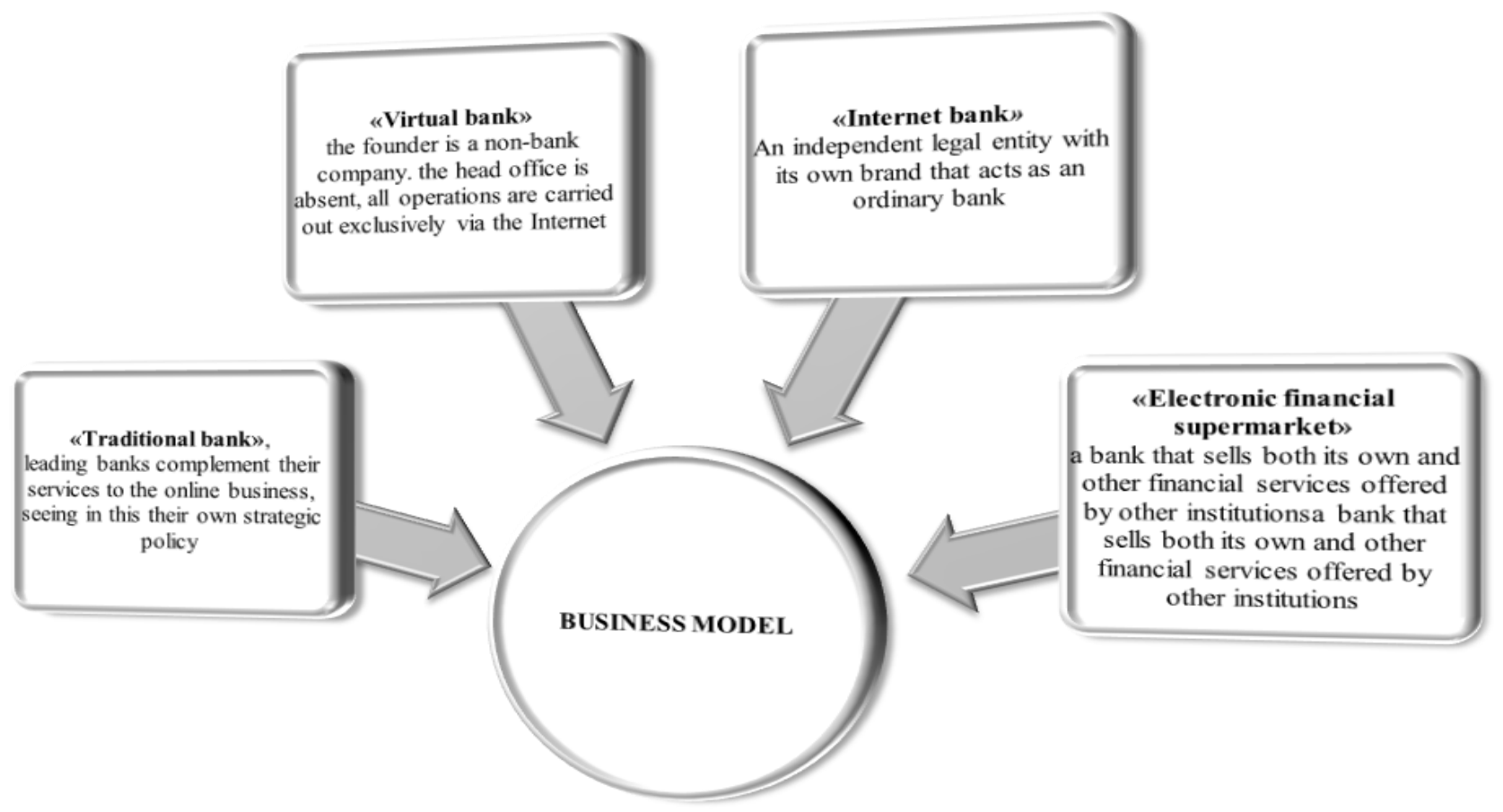

Fig. 3. Internet Banking Models

Source: built by the authors

Analyzing the world practice of electronic banking, Poland is choosen as an example. Bank Zachodni WBK is the third largest bank in Poland at the expense of its property. The Bank concentrates its activities on the management of assets, investments, leasing, factoring, insurance services and brokerage activities. There are about 900 offices in which more than 3 million clients are served. In the case of mobile banking, the bank BZ WBK offers a BZWBK24 mobile phone, with the ability to monitor accounts on the phone's desktop constantly. Mobile banking is based primarily on mobile applications BZWBK24 and PeoPay, which are characterized primarily as a free and convenient and understandable application. They allow you to transfer and control the funds on the account quickly and pay with NFC contactless. If the account does not exceed 50 zloty, then click «OK», while the amount over 50 zloty requires a 4-digit PIN. At the moment, this application provides great convenience, since there is no need to carry cash or a credit card. The growing popularity of these applications has led to an almost ten times increase in the number of deals in 2017 - more than 2177 million transactions, while in 2015 it was only 219,000. The number of mobile banking operations and the number of their active users in 2015-2017. shown in Figure 4. 


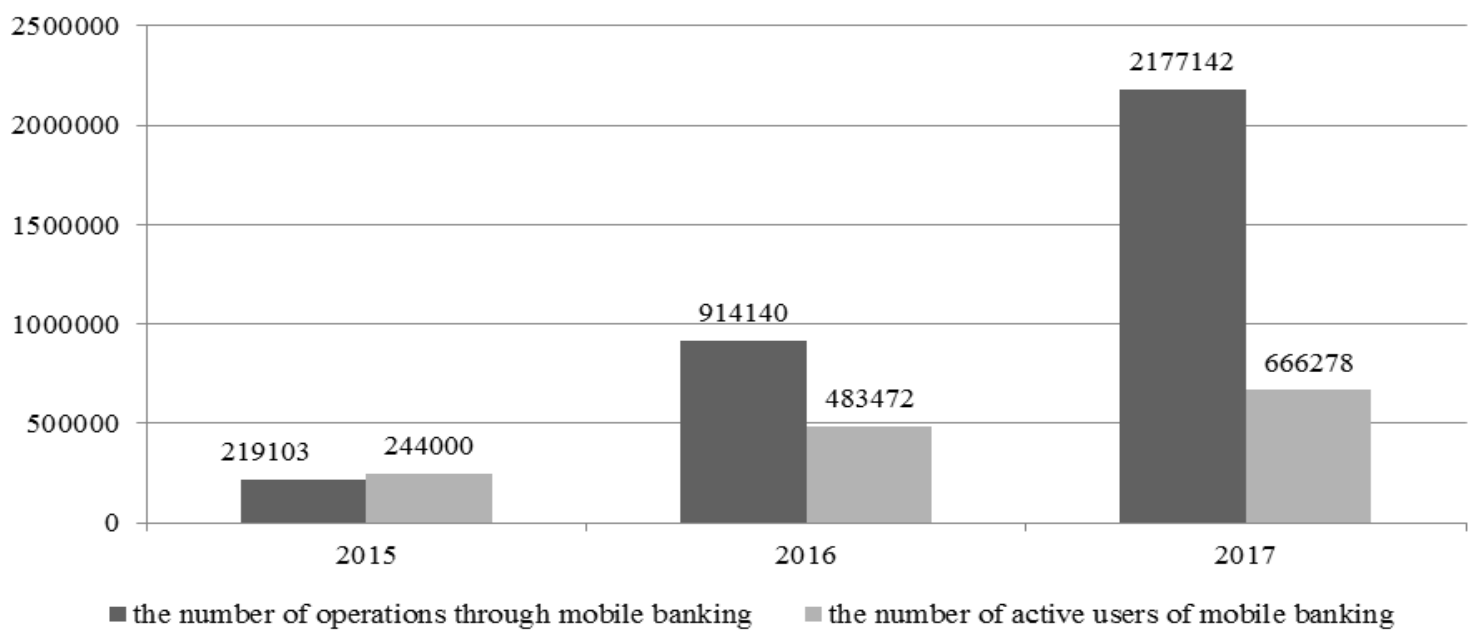

Fig. 4. The number of mobile banking operations and the number of their active users in $2015-2017$

Source: own development based on data provided by BZWBK

When it comes to active mobile banking users, namely young people between the ages of 18 and 26, their number for the period under the study increased almost threefold. At the end of 2017 there were more than 666 thousand users, which is 422 thousand users more than in 2015.

In 2017, more than 2.8 million customers had access to Internet Bank. Compared to 2015, this figure is increasing annually by almost 100 thousand users. Of all clients having an agreement with a bank, BZWBK24 uses the Internet almost $60 \%$ at least once a month go in their savings accounts. The number of individual clients is shown in Figure 5.

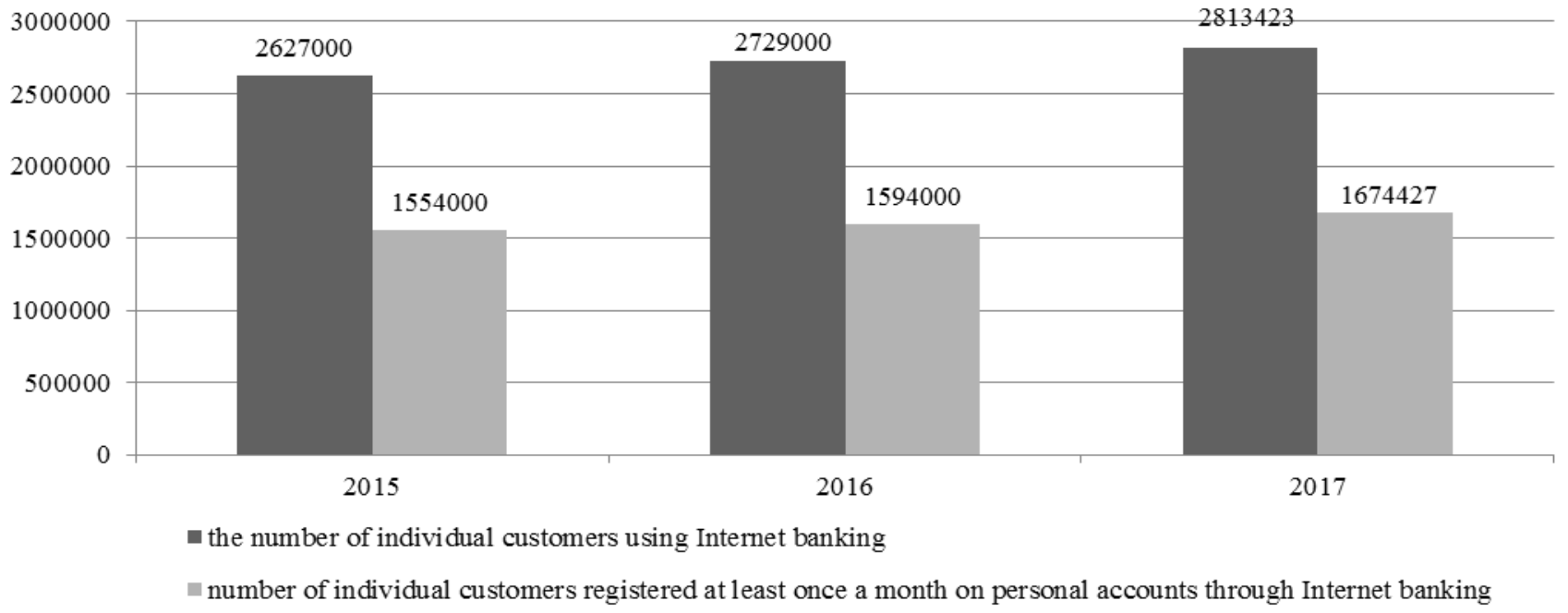

Fig. 5. Number of Individual Customers

Source: own development based on data provided by BZWBK

Among the digital banking services, most customers (63\%) use only online banking, and one in three combines Internet banking services with mobile banking. In contrast, only $4 \%$ are those who support only their bank 
account with the help of mobile banking. Schematically depicts the structure of electronic banking clients in Figure 6.

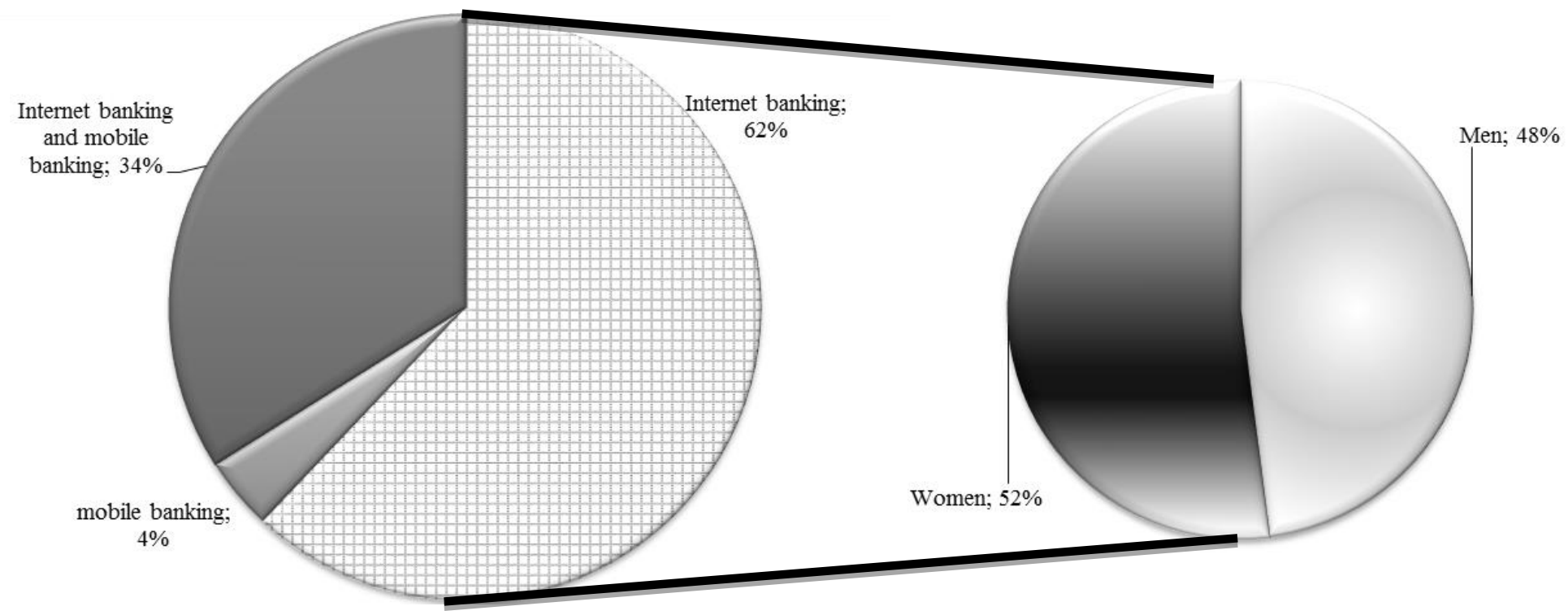

Fig. 6. Structure of electronic banking clients

Source: own development based on data provided by BZWBK.

Among the digitized clients of the Zachodni Bank, the majority is women, as shown in Figure 6. The largest age group of women is between the ages of 27 and 35. Immediately behind them a small group of people aged from 36 to 50 years. The number of clients registered on the BZWBK 24 Internet platform over the age of 50 can be compared with the number of clients aged from 18 to 26 years. Young clients are usually more ambitious, active, and above all innovative. Those who have reached the retirement age are much less interested in modern technologies.

It is also worth analyzing banks in Poland, for example, MBANK, PKO BP and Eurobank, which offer their customers the ability to use different types of online accounts, and the client, choosing Internet accounts, is controlled by the number of fees. Different packages on the example of the proposed banks (in comparison) are shown in Table 1.

Table 1. Comparison of subscription costs - SMS message

\begin{tabular}{|c|c|c|c|c|c|c|}
\hline Peculiarity & \multicolumn{3}{|c|}{ MBANK } & PKO BP & \multicolumn{2}{c|}{ Euro bank } \\
\hline $\begin{array}{c}\text { Message } \\
\text { number }\end{array}$ & I-20 SMS & II 45 SMS & III 90 SMS & I-40 SMS & $\begin{array}{c}\text { Optimum } \\
15 \text { SMS }\end{array}$ & $\begin{array}{c}\text { Premium } \\
50 \text { SMS }\end{array}$ \\
\hline Charge & 3,00 ZL & $6,00 \mathrm{ZL}$ & $9,00 \mathrm{ZL}$ & $6,00 \mathrm{ZL}$ & $2.50 \mathrm{ZL}$ & $6,00 \mathrm{ZL}$ \\
\hline
\end{tabular}

Source: own research based on (Dostęp do serwisy transakcyjnego iPKO oraz iPKO biznes, przeglądany 12.02.2018)

The largest fee from customers is traced to Eurobank - up to 9 zlotys. MBANK and RKO BP allow you to use mobile payments with your smartphone as a Blik service. The cost of SMS notification of mobile payments in the analyzed banks is different: PKO BP offers 0,25 zloty for 1 SMS, MBANK - r equires a fee of 0,35 zloty.

MBANK's customers have the largest selection of subscriptions. The 90 SMS package costs only 9 PLN, which is very beneficial for a potential client who is actively using Internet services and mobile banking. Eurobank's 


\section{ENTREPRENEURSHIP AND SUSTAINABILITY ISSUES}

ISSN 2345-0282 (online) http://jssidoi.org/jesi/ 2019 Volume 7 Number 1 (September) http://doi.org/10.9770/jesi.2019.7.1(17)

premium subscription is different from the other, so you can receive up to 50 SMS messages for 6 zł. Nevertheless, it allows the user to take advantage of the service - a financial manager.

According to research by the company Juniper Research, by the end of 2019 more than 1.75 billion mobile phone owners (every third inhabitant of the Earth) will use their gadgets for banking operations. By comparison, in 2014, about 800 million people used the services of mobile banking. Worldwide. At the same time, it should be noted that in Ukraine, the number of Internet users is increasing (The Statistics Portal).

In 2018, in Ukraine, it is ccounted up to $65 \%$ of Internet users from the total number of inhabitants, while in developed countries this figure reaches $90 \%$. Experts predict that for 2-3 years there will be an active increase in the number of Internet users. Over the past two years, the offer of online banking from big banks has increased. Such a service appeared in Savings Bank, as well as Raiffeisen Bank Aval. Electronic banking is most widespread in the United States, where almost every major bank and the vast majority of medium and small banks provide their clients with remote account management via the Internet. In the US, the most famous banks, such as Bank of Internet USA, EverBank Direct, BankSimple and PerkStreet Financil, specialize in online banking services. The US Internet banking market is one of the most developed in the world. This primarily reflected in the fact that the US bank customer can get the maximum number of services via the Internet, all transactions in the account, purchase / sale of currency trading on the stock markets, deposit insurance, credit, access to personalized financial information and more. According to the research «comScore», in the US in the number of internet banking holders of deposits in the ten largest banks increased to 65 million. And just pay various bills through a network of about $66 \%$ of US consumers (Chyb O., 2017). Table 2 shows the list of domestic banks that provide Internet banking services in modern conditions.

Table 2 Internet banking services of domestic banks

\begin{tabular}{|c|c|c|c|}
\hline Bank's name & $\begin{array}{l}\text { Internet banking } \\
\text { system }\end{array}$ & & Opportunities \\
\hline PrivatBank & Privat24 & \multirow{8}{*}{$\begin{array}{l}\text {-view account } \\
\text { statements; } \\
\text {-any types of } \\
\text { payments; }\end{array}$} & -registration of deposit \\
\hline Ukrsotsbank & Internet banking & & -change of currency; \\
\hline Prominvestbank & PIB-ONLINE & & -refill a mobile phone account; \\
\hline Alfa Bank & My Alfa-Bank & & -additional services on payment cards. \\
\hline OTP Bank & OTPdirekt & & $\begin{array}{l}\text {-deposit registration; } \\
\text {-currency exchange } \\
\text { - refill a mobile phone }\end{array}$ \\
\hline \multirow{3}{*}{ UkrEximBank } & \multirow{3}{*}{ Financial Portal } & & -currency exchange. \\
\hline & & & -mobile phone replenishment. \\
\hline & & & $\begin{array}{l}\text { - replenishment and withdrawal of funds from a } \\
\text { savings account. }\end{array}$ \\
\hline
\end{tabular}

Source: grouped by the authors

PrivatBank, the first Ukrainian bank to introduce Internet banking in its services, was held in 1998. Among the banks that are actively moving towards the development of Internet banking, one can distinguish PrivatBank, Ukreximbank, OTP Bank (Jesina, 2013).

Today, most experts consider mobile banking to be the most promising electronic channel for the delivery of banking services, because it allows you to implement an effective marketing concept «a bank that is always with you» (Vachnyk, 2003). An average client of a retail bank in developed countries should collaborate with him as follows: through a branch - 1-2 times a year; through the Call Center or the TV Banking System (IVR) - 5-10 times a month; through an ATM - 3-5 times a month; via the Internet - 7-10 times a month; through a mobile phone - 20-30 times a month. 
There are several main reasons that encourage banks to implement their online banking, namely: a significant demand for such a service; minimal cost; significant competitive advantage. Despite the fact that Internet banking has arisen relatively recently, in Western Europe, every fifth resident enjoys such a service. According to The Statistics Portal, today the number of users and the volume of Internet banking operations are driven by Norway $90 \%$ of the population, Finland $-86 \%$, Estonia $-81 \%$, United Kingdom - 58 \%, USA - $57 \%$, Germany and Austria $-51 \%$ (The Statistics Portal).

The forms of electronic banking provide the same range of services, but they also have key differences: when using mobile banking, access is only through a telephone and a tablet; access to Internet banking can be done through a stationary computer, a laptop, a tablet and a smartphone. The advantages and disadvantages of mobile banking and Internet banking in Table 3 are described in detail.

Table 3 Advantages and disadvantages of mobile banking and Internet banking for customers and banking institutions

\begin{tabular}{|c|c|c|c|}
\hline \multicolumn{2}{|c|}{ Advantages } & \multicolumn{2}{c|}{ Disadvantages } \\
\hline for customers & for banks & for customers & for banks \\
\hline $\begin{array}{c}\text { round-the-clock service } \\
\text { regardless of where you are }\end{array}$ & expansion of the client base & $\begin{array}{c}\text { inaccessibility in the case of } \\
\text { technical malfunctions in the } \\
\text { system }\end{array}$ & $\begin{array}{c}\text { high cost of software } \\
\text { development and support }\end{array}$ \\
\hline $\begin{array}{c}\text { ease of use } \\
\text { and portability }\end{array}$ & increase in operating income & $\begin{array}{c}\text { need to obtain relevant } \\
\text { knowledge }\end{array}$ & $\begin{array}{c}\text { increase the level of } \\
\text { operational risks }\end{array}$ \\
\hline $\begin{array}{c}\text { the cost of service is much } \\
\text { lower than the service at the } \\
\text { department }\end{array}$ & $\begin{array}{c}\text { strengthening of competitive } \\
\text { positions in the market of } \\
\text { banking services } \\
\text { inability to access in the } \\
\text { absence of the Internet or } \\
\text { mobile phone }\end{array}$ & $\begin{array}{c}\text { in the event of frequent } \\
\text { failures in the system, the } \\
\text { probability of reputational risk } \\
\text { increases }\end{array}$ \\
\hline $\begin{array}{c}\text { possibility of realization of a } \\
\text { wide spectrum of services and } \\
\text { constant control of accounts }\end{array}$ & $\begin{array}{c}\text { reduction the cost of } \\
\text { maintaining staff and } \\
\text { departments }\end{array}$ & $\begin{array}{c}\text { increase the risk of illegal } \\
\text { obtaining of personal data by } \\
\text { third parties }\end{array}$ & $\begin{array}{c}\text { increase the likelihood of } \\
\text { fraud and virus attacks }\end{array}$ \\
\hline $\begin{array}{c}\text { operationality of conducting } \\
\text { transactions }\end{array}$ & $\begin{array}{c}\text { expanding the range of } \\
\text { services }\end{array}$ & $\begin{array}{c}\text { nsufficient protection against } \\
\text { fraudsters }\end{array}$ & $\begin{array}{c}\text { dependence on Internet } \\
\text { providers }\end{array}$ \\
\hline
\end{tabular}

Source: developed by the authors

In Ukraine, consumers appreciate the branching out of branches and ATMs, which indicates that they favor contact service. For them, the quality of service and service is important, despite the fact that among the trends of recent years is the reduction of bank branches and the number of staff through optimizing the costs of banks. At the same time, Internet marketing, mobile marketing and other multi-channel communications are increasing. Under these conditions, the role of marketing tools that influence the formation of a high level of quality of service for consumers (Rechetnikova I., Chapovalova E., 2017).

Among the reasons that hinder the development of e-banking in Ukraine (especially Internet banking and mobile banking), one can distinguish:

1) the absence of legislative acts regulating the relations between banks and their clients in the process of using electronic banking;

2) low level of trust of the part of clients (especially among the elderly) to technological innovations;

3) lack of high-speed access to the Internet, especially in rural areas.

Studies conclude that both internal and external factors significantly influence the performance of banks. There are number of explanatory variables that have been utilized to measure the performance of banks. (Xu et al., 2018; Kunitsyna et al., 2018). 


\section{ENTREPRENEURSHIP AND SUSTAINABILITY ISSUES}

ISSN 2345-0282 (online) http://jssidoi.org/jesi/ 2019 Volume 7 Number 1 (September) http://doi.org/10.9770/jesi.2019.7.1(17)

A significant factor inhibiting the development of innovative forms of e-banking is the financial and political situation in Ukraine, which creates unfavorable conditions for banking business, which leads to the liquidation of banking institutions and the withdrawal of foreign banks from the domestic financial services market (Sodoma R., 2018). Under such conditions, the share of banks actively investing in the development of advanced forms of banking services in our country is still insignificant.

\section{Conclusions and perspectives of further research}

The article proposes the basic factors for further development of Internet banking in Ukraine which will attract much more clients; increase speed and quality of service of client's cashless payments; develop functionality and services convenient and affordable for the clients; increase the safety of banking in general. (Shevchuk T., 2015). As a result of the study, it was found that the forms of electronic banking have undergone certain stages, which resulted in the emergence of effective and convenient tools that correlate with the advanced achievements in information technology.

Internet banking and mobile banking are creating new trends in the banking sector and become an obvious element without which functioning in the world around us is impossible. It brings with it a number of very important benefits not only for potential customers, but also for the bank. It provides customer contact with the bank through the use of the Internet. Mobile banking is the latest step in providing banking services. Its use is possible thanks to installed mobile phone banking applications.

Almost all banks that occupy leading positions in the market of banking services offer e-banking services, as it enables clients, without attending a branch of banks, to carry out a wide range of banking operations: to manage the volume of resources on their own account; exchange currency; make payments and transfers; pay for services of mobile communication, Internet, utilities, taxes, fines.

Therefore, further research should be aimed at developing an effective electronic tool that should absorb elements of existing banking products. The introduction of innovative forms of remote servicing expands the profile of traditional risks and creates new sources of their occurrence. That's why the process of identifying risks in the use of electronic banking, assessments and risk minimization techniques is a prospect for further research.

\section{References}

Bessonova E.; Domkhokova T. (2016). The technique of evaluating the efficiency of controlling adjusted for confectionary enterprises. Economic Annals-XXI, 157 (3-4(1)), 112-114. https://doi.org/10.21003/ea.V157-0035 17

Boiar, Andrii O.; Shmatkovska, Tetiana O.; Stashchuk, Olena V. (2018). Towards the theory of supranational finance, Cogent Business \& Management, 5(1) http://doi.org/10.1080/23311975.2018.1482594

Chmutova I.; Vovk V.; Bezrodna O. (2017). Analytical tools to implement integrated bank financial management technologies. Economic Annals-XXI, 163 (1-2(1)), 95-99. https://doi.org/10.21003/ea.V163-20

Chyb, O. Rozvutok internet-bankingy v globalnomy seredovuchi [Development of Internet banking in the global environment] Retrieved from http://www.nbuv.gov.ua

Dostęp do serwisy transakcyjnego iPKO oraz iPKO biznes [Access to the iPKO and iPKO biznes transaction website]. Retrieved from http://www.pkobp.pl/aktualnosci/ogolnokrajowe/dostep-do-serwisu-transakcyinego-ipko-oraz-ipko-biznes-zaktualizuj-przegladarke-nawspierajaca-protokol-tls/ 


\section{ENTREPRENEURSHIP AND SUSTAINABILITY ISSUES}

ISSN 2345-0282 (online) http://jssidoi.org/jesi/ 2019 Volume 7 Number 1 (September) http://doi.org/10.9770/jesi.2019.7.1(17)

Gracheva, M. V. (2002). Elektronnuje bankovskuje uslugu: osobennosty upravlennja ryskamu [Electronic banking services: features of risk management]. Bankovskuje technologuje, 6, 20-29. Retrieved from http://www.finnews.ru/cur_an.php?idnws=73

Jesina, O. G. (2013). Internet-banking v Ukraini: sychasnyj stan, problem ta perspektyvy rozvutku [Internet banking in Ukraine: the current state, problems and prospects of development]. Visnik socialno-ekonomichnuc doslidchen, 1(48), 209-213. Retrieved from http://vsed.oneu.edu.ua/files/full/2013/vsed_48-2013.pdf

Kisiel, M. (2007). Internet a konkurencyjnosi bankow w Polsce [Internet and the competitiveness of banks in Polsce], Warszawa. Retrieved from http://www.pte.pl/pliki/2/19/rola_bankow___angielski\%5B1\%5D-1.pdf

Kunitsyna, N.; Britchenko, I.; Kunitsyn, I. 2018. Reputational risks, value of losses and financial sustainability of commercial banks. Entrepreneurship and Sustainability Issues, 5(4), 943-955. http://doi.org/10.9770/jesi.2018.5.4(17)

Powiadomienia SMS i EMAIL [SMS and EMAIL notifications]. Retrieved from https://www.pkobp.pl/bankowoscelektroniczna/ipko/obsluga-rachunkow-i-lokat/e-wyciagi/powiadomienia-sms-i-e-mail/\#/szczegoly-oferty/

Przewodnik finansowy nbp: Bankowosc internetowa i rozliczenia w sieci [Financial advisor nbp: Internet banking and online settlements). Retrieved from http://superbiz.se.pl/wiadomosci-biz/przewodnik-finansowy-bankowosc-internetowa-i-rozliczenia-w-sieci 309432.html

Rechetnikova, I.; Chapovalova, E. (2017). Marketyngovi instrymenty zabezpechennja jakosti obslugovuvannja na runky bankivskych poslych [Marketing tools for quality assurance in the banking services market]. Marketing I menedjment innovacij, Symu, 2, 47-56. http://doi.org/10.21272/mmi.2017.2-04

Sodoma, R.; Skhidnytska, H.; Shvorak, A.; Shmatkovska, T.; \& Zhurakovska, I. (2018). Peculiarities of agrarian receipts as a modern financial tool [Peculiarities of agrarian receipts as a modern financial tool] . Economic annals - XXI, 169 (1-2), 4649. https://doi.org/10.21003/ea.V169-09

Romanenko Y. A.; Chaplay I. V. (2017). Theoretical and methodological foundations subsystem brand management at the enterprise [Theoretical and methodological foundations subsystem brand management at the enterprise] . Scientific bulletin of Polissia, 2., 156-163 Retrieved from http://journals.uran.ua/nvp_chntu/article/view/110268

Shevchuk T. (2015). Problemy ta osoblyvosti rozvytku zyfrovych bankivskych technologij [Problems and development features of digital banking technologies). Financial and credit activity: problems of theory and practice, 1(18), 249255. https://doi.org/10.18371/fcaptp.v1i18.46549

The Statistics Portal [The Statistics Portal). Retrieved from http://www.statista.com/statistics/222286/online-banking-penetration-in$\underline{\text { leading-european-countries/ }}$

Tofan I. N., Ahres O. H., Shmatkovska T. O. (2017). Problems in administration of real estate tax other than land in Ukraine [Problems in administration of real estate tax other than land in Ukraine]. Scientific bulletin of Polissia, 3(11), 148-153. Retrieved from http://nvp.stu.cn.ua/uk/component/k2/item/823-tofan-i-n-ahres-o-h-shmatkovska-t-o-problems-in-administration-of-tax-on-real-estate-

other-than-land-in-ukraine.html

Tsymbaliuk, I. O.; Shmatkovska, T. O.; \& Shulyk, Y.V. (2017). Tax alternatives to implement the tax capacity of internet activity in Ukraine [Tax alternatives to implement the tax capacity of internet activity in Ukraine]. Financial and credit activity: problems of theory and practice, Kharkiv, 22, 336-344. Retrieved from http://fkd.org.ua/article/view/110049

Vachnyk, S. V. (2003). Perspektyve dustancinogo obslygowywannja klijentiv v rezymi realnogo chasy dlja bankiv Ukraine [The prospects of remote customer service in real time for banks in Ukraine]. Problemu I perspektyvu rozvytky bankivskoji systemy Ukrainu . Symu. 184185. Retrieved from http://zavantag.com/docs/483/index-11859-1.html?page=39

Wojciechowska-Filipek, S. (2010). Technologia informacyjna w uslugach bankowosci elektronicznej, [Information technology in electronic banking services] Warszawa. 55 Retrieved from http://www.wne.sggw.pl/czasopisma/pdf/PEFIM_2010_T3_nr52.pdf

Xu, J. X.; Naiwen, L.; Ahmad, M. I. (2018). Banking performance of China and Pakistan, Entrepreneurship and Sustainability Issues, 5(4), 929-942. http://doi.org/10.9770/jesi.2018.5.4(16)

Yakubiv, V. M.; Horohotska, N. I.; Yakubiv, R. D. (2015). Upravlinska model zabezpechennya rozvytku silskogospodarskyx pidpryyemstv shltaxom vprovadzhennya dyversyfikacijnyx procesiv [Administrative model of ensuring the development of agricultural enterprises 
ENTREPRENEURSHIP AND SUSTAINABILITY ISSUES

ISSN 2345-0282 (online) http://jssidoi.org/jesi/ 2019 Volume 7 Number 1 (September) http://doi.org/10.9770/jesi.2019.7.1(17)

through diversification processes implementation]. Actual problems of economics, 8(170), 58-66. Retrieved from https://www.researchgate.net/publication/298698043 Administrative model of ensuring the development of agricultural enterprises th rough_diversification_processes_implementation

Zaleska, M. (2007). Wspolczesna bankowosc, [Contemporary banking] Warszawa Retrieved from https://cyberleninka.ru/article/v/standartizatsiya-bankovskih-produktov-uslug-i-kanalov-ih-rasprostraneniya

Valentyna YAKUBIV is the Doctor in Economics, Professor and Head of the Department of Management and Business Administration at Vasyl Stefanyk Precarpathian National University, Ukraine (UA). Her work has attracted the scholarship of the Cabinet of Ministers of Ukraine for young scientists as well as the grant of the President of Ukraine for young scientists. The author coordinated the work of the author's team on this research. Research interests: strategic management and planning, management in the field of innovative agriculture.

Scopus Author ID: 56294400400

ORCID ID: orcid.org/0000-0002-5412-3220

Ruslana SODOMA is the Ph.D. in Economics and Associate Professor of the Department of Finance, Banking and Insurance at Lviv National Agrarian University, Ukraine (UA). Her work has attracted the Diplomas of the Lviv National Agrarian University. The author analyzes the phases of Internet banking development, forms of electronic banking, and compares the electronic banking clients of Ukraine and Poland. Research interests:: lending to agrarian enterprises; internet banking; bank lending operations.

Scopus Author ID: 56669972700

ORCID ID: orcid.org/0000-0002-5020-6440

Oksana HRYTSYNA is the Ph.D. in Economics and Associate Professor and Head of the Department of Finance, Banking and Insurance at Lviv National Agrarian University, Ukraine (UA). Her work has attracted the Honorary Diploma of the Lviv Regional State Administration, Diplomas of the Lviv National Agrarian University. The author outlined the advantages and disadvantages of mobile banking and Internet banking for clients and banking institutions. Research interests:: current state of insurance; innovations in the banking sector; electronic banking.

ORCID ID: orcid.org/0000-0002-1304-0250

Natalia PAVLIKHA is the Doctor of Economics and Professor and Vice-rector for Scientific work and Innovations at Lesya Ukrainka Eastern European National University, Ukraine (UA). Her work has attracted the breastplate of the Ministry of Education and Science of UA as well as the silver breastplate of the Lesya Ukrainka Eastern European National University. The author systematized the material, that was studied in this research. Research interests: spatial development, regional economics, international economics, project management.

ORCID ID: orcid.org/0000-0001-5191-242X

Tetiana SHMATKOVSKA is the Ph.D. in Economics and Associate Professor of the Department of Accounting and Audit at Lesya Ukrainka Eastern European National University, Ukraine (UA). Her work has attracted the scholarship of the Cabinet of Ministers of Ukraine for young scientists as well as the silver breastplate of the Lesya Ukrainka Eastern European National University. The author systematized the material, that was studied in this research. Research interests: accounting and analytical support for the management of business entities, banks, enterprises, etc.

Scopus Author ID: 57203187237

ORCID ID: orcid.org/0000-0003-2771-9982 


\section{ENTREPRENEURSHIP AND SUSTAINABILITY ISSUES}

ISSN 2345-0282 (online) http://jssidoi.org/jesi/ 2019 Volume 7 Number 1 (September) http://doi.org/10.9770/jesi.2019.7.1(17)

Iryna TSYMBALIUK is the Ph.D. in Economics and Associate Professor of the Department of Finance, Banking and Insurance at Lesya Ukrainka Eastern European National University, Ukraine (UA). Her work has attracted the Honorary Diplomas of the Lesya Ukrainka Eastern European National University. The author completed the design of the material, that was studied in the research. Research interests: finance, taxation, regional economics.

ORCID ID: orcid.org/0000-0001-7224-2365

Olga MARCUS is the PhD in Economics and Associate Professor of the Department of Accounting and Audit at Lesya Ukrainka Eastern European National University, Ukraine (UA). Her work has attracted the silver breastplate of the Lesya Ukrainka Eastern European National University. She is currently editing a series on accounting in banks. Research interests: accounting in banks, regional spatial development, investment projects in communal economy.

ORCID ID: orcid.org/0000-0002-6147-888X

Iryna BRODSKA is the PhD in Economics and Associate Professor of the Department of Accounting and Audit at Lutsk National Technical University, Ukraine (UA). The author also completed the design of the material, that was studied in the research. Research interests: introduction of international standards of financial reporting in credit institutions, problems of the control in credit unions.

ORCID ID: orcid.org/ 0000-0003-4211-0606

Register for an ORCID ID:

https://orcid.org/register

Copyright (C) 2019 by author(s) and VsI Entrepreneurship and Sustainability Center

This work is licensed under the Creative Commons Attribution International License (CC BY).

http://creativecommons.org/licenses/by/4.0/

cC) (i) Open Access 